\title{
China's Accession to Government Procurement Agreement under the Trump Administration's Trade Policy
}

\author{
Feng Guo ${ }^{1}, \&$ Fen Zhou $^{2}$ \\ ${ }^{1}$ School of Public Finance and Taxation, Central University of Finance and Economics, Beijing, China \\ ${ }^{2}$ School of Law, Central University of Finance and Economics, Beijing, China \\ Correspondence: GUO Feng, School of Public Finance and Taxation, Central University of Finance and \\ Economics, 39 South College Road, Haidian District, Beijing 100081 China.
}

Received: October 12, 2019

Accepted: December 24, 2019

Online Published: December 26, 2019

doi:10.5539/ibr.v13n1p237

URL: https://doi.org/10.5539/ibr.v13n1p237

\begin{abstract}
China committed to initiate the accession to Government Procurement Agreement when it entered the WTO as a compromise to the requirements made by GPA parties, mostly the developed western countries such as the United States. China started its official attempt to join the GPA on December 28, 2007 by submitting the first offer to the GPA Commission. Six revised offer were then submitted during the past years. The position of the United States and China in international trade changed dramatically since then. This article finds that Trump Administration's attitude toward China's accession to GPA is mixed and the US government might impede China's accession with the analysis on the current American foreign trade policy and the latest development in government procurement in the US's related international agreements and domestic laws. However, this accession process can only be delayed but not terminated even if the standpoint of the US is proved to be negative due to the theoretical and technical analysis on GPA. Effective and significant measures will be taken by Chinese government since the president Xi Jinping made the statement to accelerate the accession to GPA in Boao Forum in early 2018.
\end{abstract}

Keywords: government procurement agreement, US foreign trade policy, China's accession, countermeasures

\section{Introduction}

Government procurement is an important financial tool for all the governments and the open-up of markets of government procurement is the requirement of globalization. China's promise to accede to Government Procurement Agreement was made under the pressure of GPA members, mostly developed countries such as the United States, when China became a WTO member after long-term hard negotiation. Trump is elected to be American president when globalization faces the biggest challenges in recent years because of the imbalance and interest conflicts coming with it. An American first foreign trade policy was promoted and implemented by Trumps' Administration which seems to be more protectionist. Meanwhile, the Chinese government shows its positive attitude towards trade liberalization with the idea to build a Community of Human Destiny and the "One Belt and One Road" Initiative. American and Chinese governments' positions change greatly compared to the standpoint they held when China submitted its first offer to GPA commission in 2007. The escalating trade war between the U.S. and China brought even more uncertainty for China's accession process.

This article starts with the observations on the strategic shift of US-China trade policy, and introduces the analysis on the latest development of the US's international agreements related to government procurement. It then attempts to clarify the American and Chinese governments' changing attitudes towards China's accession to GPA, and finds that China's accession to GPA can only be delayed but not terminated even under the hypothesis that the United States adopts a negative attitude under Trump Administration. Several countermeasures that China might adopt to accelerate its accession to GPA are listed in the last part.

\section{Trump Administration's Trade Policy Towards China under the Discontents of Globalization}

\subsection{Anti-Globalization in the Foreign Trade Strategy and Policies of Trump Administration}

Economic globalization refers to the process of global economic activities that transcend national borders and form a global economy through foreign trade, capital flows, technology transfer, service provision, interdependence and interconnection. The theory of globalization believes that economic globalization is a 
significant trend in the development of the world economy. Developed countries, as the founders of the current economic globalization rules, are generally considered to be benefited the most from the progress of globalization. However, the non-equilibrium characteristics of economic globalization have also led to widening gaps among different groups of people and more intensified conflicts of interest in the world. Multinational corporations, financial groups and their investors are the real beneficiaries of economic globalization rather than the general public. (Stiglitz, 2018) The middle class and working class in the United stated suffer the negative effects of increasing unemployment, the hollowing out of Manufacturing and an increase in the Gini coefficient. The new discontents of globalization explain why Trump was elected to be the president of the United States and promoted an foreign trade strategy of anti-globalization.

The United States used to be the major promoter of globalization and opening foreign trade policy after WWII. As the first country to submit the proposal in Article 9 of the Suggested Charter for an International Trade Organization of the United Nations (ITO, the predecessor of GATT) in 1946 urging international trade arrangements to reduce barriers to procurement markets and to cover government procurement in general non-discrimination obligations (Feis,1947) and one of the original signatories of Government Procurement Agreement (GPA), the United States worked with OECD and other developed countries to promote the opening of the government procurement market and trade liberalization, established the framework of Government Procurement Agreement (GPA) and had always been promoting other countries to open their government procurement markets to the U.S. and join the GPA. (Arrowsmith, 2003; Yukins\&Schooner, 2007; Anderson\&Arrowsmith 2011; Harutyunyan, 2016; Yukins, 2017) U.S. Government Accountability Office reported to congressional requesters that the U.S. opens more procurement opportunities covered by the GPA to foreign firms than had other parties to this agreement in May 2019. The United States was the main power to support and require China's accession to GPA in China's negotiation to accede to WTO.

Trump's foreign trade policy can be concluded as a fair, balanced trade policy focusing on American first. His National Security Strategy published in 2017 reiterated the American first foreign policy as he proposed in election and emphasized the free, fair and balanced economic relationship. This trade policy is stated as the pursuit of fair, balanced trade relationship in the 2018 Trade Policy Agenda and 2017 Annual Report. Under Trump Administration, American foreign trade policy transforms from supporting and advocating economic globalization to protectionism, from multilateral mechanism to bilateral trade negotiation, from actively applying WTO international trade dispute settlement mechanism to implement unilateral sanctions under domestic laws, from defending the current international trade system to advancing the reform of the international trade system. It aims to build a new global trade order that is more in line with American national interests, including national security, development of American manufacturing, elimination of trade deficits, decrease of unemployment and economic growth in the United States.(Hoda, 2019; Yong, 2019)

\subsection{The Changed Strategic Judgement on China Influenced by National Interest}

The sovereign countries are like the rational person in the international political market and therefore the national interest is the most important factor affecting the interaction between countries. Based on its national interest, the United States used to regard China as an emerging and transitional country and treat China as a possible strategic partner by advancing the reform of Chinese law and regulations, requiring China to strictly abide by the international trade regulations and open its large market, promoting China to be a fair participator of the global competition, with the aim to benefit the national interest of United States. The Obama administration's China policy is the policy of engagement as stated in his last Trade Policy Agenda in 2016 to robust U.S. engagement with China and work bilaterally, multilaterally at the WTO, to open China's market through all available tools including dialogue and negotiation. China was still regarded as the possible strategic partner under Obama's administration with the effort to maintain the constructive cooperation relationship in his National Security Strategy in 2015.

Trump Administration not only refers to China as a revisionist country and a strategic competitor or rival in official documents, but also ranks China and Russia as the first threat to U.S. national interest before rogue regimes and terrorists which used to be ranked as the third one in the Obama administration's Trade Policy Agendas. Trump Administration's National Security Strategy stated that China cannot become a trustworthy partner through engagement policy because China has challenged U.S. national strength, influence and interests with the attempt to weaken U.S. security and prosperity. The U.S. Department of Defense positioned China's strategic competition as the highest priority in the 2018 National Defense Strategy of the USA. It can be concluded that the Trump administration's strategic judgement on China has been transformed from a potential strategic partner to a strategic competitor or rival. 


\subsection{The U.S. Trade Policy Towards China}

Trump's main trade policies towards China are reflected in the Report to Congress on China's WTO Compliance, the report of How China's Economic Aggression Threatens the Technologies and Intellectual Property of the United States and the World, Special 301 Report and Findings of the investigation into China's Acts, Policies and Practices Related to Technology Transfer, Intellectual Property and Innovation under Section 301 of the Trade Act of 1974, etc. The studies on these official documents find that the current U.S. trade policy towards China has shifted from dialogue to containment and from engagement to decoupling in order to construct a fair, reciprocal and balanced U.S.-China trade relationship.

Trump's China trade policy constitutes four main parts. Firstly, U.S. denies China's market economy status in WTO and attempts to interfere with China's new free trade agreements with other countries with a "poison pill" clause in US-Mexico-Canada Agreement (USMCA, the result of a renegotiation of NAFTA) . Secondly, Trump Administration makes great effort to hinder China's innovation and high-tech development and uses all available tools to address the "Made in China 2025" strategy. Thirdly, current WTO rules are challenged. The U.S. government is promoting reforms and prefers the domestic laws such as Section 301 rather than the WTO dispute settlement mechanism. Fourthly, discontents are proposed to the special treatment China enjoys or expects as a developing country and more responsibilities and obligations are required to be taken by China according to its economic status.

\section{The U.S. International Agreement Related to Government Procurement}

As the implementation of the obligations of the United States under international agreements, the U.S. Trade Agreements Act of 1979 and Executive Order 12260 authorize the U.S. Trade Representative on behalf of U.S. president to exercise the waiver of discriminatory purchasing requirements to the Government Procurement Agreement (GPA) and parties of other free trade agreements (FTA) related to government procurement, and will provide "appropriate reciprocal competitive government procurement opportunities to United States products and suppliers of such products". This waiver is regulated in Section 402 and 403 in Federal Acquisition Regulation which seems to be fully implemented. However, its implementation in practice is doubted.(Weiss \&Thurbon, 2006) The purchasing entities has to annually report to the Congress the details of this waiver including quantity and sources and therefore face heavy pressure to apply this waiver. European Commission has reported that uncertainties exists in American practice because this waiver is not applied automatically but has to be confirmed by the specific procuring case.

\subsection{Government Procurement Agreement}

As a plurilateral agreement, GPA is not part of the multilateral mechanism of WTO. GPA provides a negotiation platform based on the principle of reciprocity and bilateral negotiation. The acceding party has to negotiate with the GPA members in plurilateral or bilateral way and confirmed its market access commitments in seven annexes of the agreement, including central entities, sub-central entities, other entities, goods, service, construction service and general note. These commitments can be different upon different GPA members. As one of the initial contracting parties of GPA, the United States is the party offering most procurement opportunities under GPA. (U.S. Government Accountability Office, 2019) GPA members are mostly developed countries and the special treatment for developing members of GPA is only applied to Israel in GPA 1994 and Moldova in GPA 2014 because the bilateral negotiation under the reciprocal principle is mainly decided by the country power. The U.S. applies numerous derogations from the Most-Favored-Nation principle through reciprocal conditions in its annexes to GPA and other international agreements such as its agreement with Canada in 2010.

\subsection{Free Trade Agreements Related to Government Procurement}

The United States has signed FTAs with GPA parties and non-GPA parties. It provides lower thresholds and more market access opportunities to GPA parties in the FTAs than had it offered under GPA which can been found from the Federal Register Notice with 2018-2019 Thresholds (82 FR 58248, Dec. 11, 2017). More procuring opportunities are open to some partners in the FTAs which are not GPA parties, such as the US-Central America-Dominica Free Trade Agreement, the US-Chile Free Trade Agreement, etc.(Anderson, Müller, Osei-Lah, Leon, \& Pelletier, 2011)

With the Fast Track Authority (FTA), Trump is authorized to accelerate the legislative process of international agreements in the United States. In the pursuit of fair and reciprocal trade relationship, Trump Administration withdrew from the Trans-Pacific Partnership Agreement (TPP) and replaced the North American Free Trade Agreement (NAFTA) with the US-Mexico-Canada Agreement (USMCA), revised the US-Korea Free Trade Agreement (KORUS), delayed US-EU Cross-Atlantic Trade and Investment Partnership Agreement (TTIP), and 
started new negotiations with Japan and Britain. The latest government chapters of USMCA and KORUS are mostly copied from GPA directly or indirectly.

USMCA, as the "paradigm-shifting model" of U.S. trade policy called by U.S. Trade Representative Robert Lighthizer, is a model for new trade deals with the United States. Therefore it is an important reference for China's GPA accession negotiation with the United States. It is paid most attention that the remaining parties can exit USMCA in 6 months to sign a bilateral agreement if any other party reaches a free trade agreement with a "non-market economy". China is regarded as a non-market economy (NME) by the U.S. Department of Commerce under the U.S. antidumping and countervailing duty laws. The statements in 2019 Trade Policy Agenda of the United States makes it clear that this clause aims at China.

When compared the chapter of government procurement in USMCA (chapter 13) with the text of TPP Chapter 15 , the content of this chapter in USMCA is mainly taken from TPP. The text of TPP is largely learned from GPA. (Gorski, 2016) This reflects that GPA is still the best practice for the U.S. national interests in international agreements.

NAFTA, the former agreement USMCA is built on, has set a deal for United States, Mexico and Canada about government market access. The United States and Canada signed an government procurement agreement in 2010 to open more procurement opportunities to each other. However, Article 13.3 of USMCA makes it clear that the government procurement chapter only applies to the United States and Mexico, and excludes Canada. The government procurement between Canada and the United States will be directly governed by GPA. Canadian and the U.S. vendors might get more limited accede to the other country's government procurement market than under the NAFTA. (Yukins, 2018)

\section{Changing Attitudes Toward China's Accession to GPA}

\subsection{The American Side of the Story}

The Trump administration stressed the needs to strengthen the implementation of the "buy American" provisions, and asked the U.S. Department of Commerce to assess the impacts upon "buy American" principle caused by the international agreements including GPA. This caused the international community to worry that the United States might start renegotiation or exit the existing agreements related to government procurement including GPA.

The U.S. government is still committed to improve and promote the trade rules under the WTO framework although Trump has repeatedly expressed dissatisfaction with the multilateral trading system and intended to achieve the U.S. national interests through bilateral negotiations. The appeals and efforts made by the Trump Administration to reform WTO rules does not mean to abandon or withdraw from the multilateral trading system. The pursuit for the greatest government procurement market accede to other countries with least cost in the U.S. trade policy (Weiss\&Thurbon, 2006) can only be realized upon appropriate platform.

With the fundamental principle of reciprocity, GPA is the right platform for the current U.S. negotiation preference. The coverage of GPA is made through bilateral negotiations while the adjustment of domestic regulations is promoted in a plurilateral way.(Arrowsmith, 2003) The mode GPA creates is in line with Trump's advocacy for the negotiation of international trade agreements for fair, reciprocal and balanced trade relationship focusing on American first. Therefore, GPA can not be abandoned by the U.S. as a effective and efficient tool for government market accede to other countries. The USMCA negotiation and final outcomes also show the U.S. attitude to GPA including the text comparison and the exclusion of Canada in the government procurement chapter.

China submitted its first offer in January 2008 according to its commitment made in 2001 for its successful accession to the WTO. Five revised offers have been offered in July 2010, November 2011, December 2013 and December 2014 as the outcomes to China's bilateral and plurilateral negotiations with the United States and other GPA parties. The fifth revised offer made significant improvement comparing with the past offers and the Ministry of Finance of China stated that this coverage is basically at the same level as the current GPA parties. However, it is still far beyond the GPA parties' expectation according to the report of Committee on Government Procurement in 2017. China promised to submit an updated offer in the meeting of GPA committee in February 2017 to improve the coverage of sub-central entities and state-owned enterprises. China appealed that the GPA parties treat China's offer in a more pragmatic way and consider the special treatment for China as a developing country. The Ministry of Commerce of China submitted the sixth revised offer in October 2019.

The United States submitted the comments on the improvement for China's first offer and the following revised offers, responded to China's checklist submitted to GPA committee, and achieved China's promise to submit new revised offer in December 2013 in China-US Joint Commission on Commerce and Trade (JCCT). The American 
efforts can be seen with every offer and every improvement China made. The last Trade Policy Agenda of the Obama administration clearly confirmed the will to actively promote China's accession to GPA to balance the U.S.-China trade and expand the opening of the large government procurement market of China.

Will the Trump Administration oppose China's accession to GPA? The answers might be found in the changes of the U.S. foreign trade policy and strategic judgement of China, the assessment on the international agreements based on "buy American" laws, the formal expression that the United States "erred in supporting China's entry into the WTO, and the escalating U.S.-China trade war. The Trump Administration "engaged in" improving the accession negotiations of other countries to GPA such as Russia, Tajikistan, Kyrgyzstan. The progress of China's accession to GPA has not been similarly stated for. Furthermore, 2018 USTR Report to Congress on China's WTO Compliance which stated the U.S. support to China's entry into WTO as an error also viewed that China's latest revised offer to GPA is still "disappointing" and "far from acceptance to the United States and other GPA parties". Trump might choose the measures of stalling or deferring China's accession to GPA to avoid embarrassment in his political base, which might ask why China is being afforded access to the U.S. federal procurement market at the same time that specific Chinese vendors, such as Huawei, are being excluded as perceived security threats. (Yukins, in press) These all deepened the concern that the Trump administration will object to China's accession to GPA.

Evidence to the contrary also can be see that GPA provides a platform for the United States to open other countries' government procurement market including China's large market through bilateral negotiations which is in line with Trump's inclination. The Trump Administration does not assert the abandon of WTO system although it insists on the reform of it. The United States is organizing the bilateral dialogues with China about the accession progress annually under Trump Administration. The waiver of discriminatory provisions is not fully implemented in American legal practice due to the analysis above. Therefore it can be concluded that the U.S. will not abandon GPA directly especially when it is engaged in greater government procurement market accession to China.

\subsection{The Chinese Side of the Story}

China's step into GPA seems slow due to the experience in the past 12 years. The Chinese government has not submitted any new offer after the fifth revised offer in 2014 until October 2019 although it committed to submit a revised offer responding to the U.S. and other GPA parties' questionings as soon as possible.

The main views of Chinese researchers have been shifted from supportive and positive (Yu, 2003; Yu, 2005; Liu, 2003; Cao\&He, 1998) to doubting and prudent(Liu, 2007; Yu, 2010; Cao, 2008). The recent escalating U.S.-China Trade war even caused the negative view and opposite voice of the Chinese researchers about the accession to GPA.(Jia, 2018)

The Chinese government proposed the concept of building a global community of human destiny and One Belt and One Road Initiative to support the globalization and trade liberalization. Chinese president Xi Jinping announced that China should accelerate the accession to GPA. This is reconfirmed at the G20 Osaka Summit in 2019 with his statement that China will accelerate the opening up to the outside world. The Ministry of Commerce of China submitted the new revised offer in October 2019 as an implementation of this highest decision.

The same clause about promised future bilateral negotiations on government procurement after China's accession to GPA has been added to China's free trade agreements with Switzerland, South Korea, Iceland, Australia and other countries since 2013. It is generally stated like that "The Parties shall commence negotiations on government procurement as soon as possible after the completion of negotiations on the accession of China to the Agreement on Government Procurement, contained in Annex 4 to the WTO Agreement, with a view to concluding, on a reciprocal basis, commitments on government procurement between the Parties." China and Israel had a consultation on the issue of government procurement for the first time in May 2019 and Israel introduced its experience about accession to GPA. China is also working on a chapter of government procurement with Norway. The above evidences reflect China's good expectation and positive attitude towards the accession to GPA.

\section{Will the Trump Administration Impede China's Accession to GPA?}

Will the United States successfully impede China's accession to GPA assuming that the Trump Administration takes an opposing attitude towards China's accession to GPA? Article 12.3 of the Marrakesh Agreement Establishing the World Trade Organization says that "Accession to a Plurilateral Trade Agreement shall be governed by the provisions of that Agreement." Article 24.2 of GPA 1994 and Article 22.2 of revised GPA 2012 
state that any Member of the WTO may accede to GPA on terms to be agreed between that Member and the Parties. Neither does the GPA nor the WTO agreement make a clear or confirmed statement about any solutions for the acceding government, a member of the WTO, when facing the denial from any GPA party. The same expression used in the two versions of GPA about making accession decision "on terms to be agreed between that (acceding) Member/Government and the Parties (of the GPA)" seems to imply that the applicant can only succeed in acceding to GPA with all the GPA parties' permission. All the negotiations completed until now have been dealt with bilateral and plurilateral dialogues and consultations. There is only accession negotiation in process but no failed ones for reference because of one or a few GPA parties insist on disagreeing with the accession.

The offer on the scope and coverage is decided by parallel bilateral negotiation based on the principle of reciprocity and balance between the two parties of the bilateral negotiation. The commitments between them are not obliged to be applied to any other GPA parties and therefore the commitments greatly differs. The reform and improvement of domestic laws and regulations in the acceding WTO members are generally carried out through plurilateral negotiation. The realization of the principle of reciprocity between GPA parties is not limited to a exactly balanced way under this negotiation mechanism.

To be exactly balanced in commitments to each other means that all the entities and thresholds in the Annexes are the same. This is easy to be implemented but too inflexible to exchange between different interests or achieve a successful outcome in complicated GPA accession negotiation. The bilateral negotiation between the United States and European Union about government procurement has been suspended in 1994 and the breakthrough was finally made by using a more flexible way to assess equal purchasing opportunities in government procurement market by a third party as the negotiation criteria. A WTO member might make commitment under other agreements in WTO theoretically in exchange for the deal made in GPA accession negotiation in addition to the above two negotiation methods, just like China's commitment for the accession to GPA for the entry into the WTO. These flexible negotiation methods provide great support and good expectation for acceding to GPA.

Article 24.11 of GPA 1994 and Article 22.14 of revised GPA 2012 state that the agreement shall not apply as between any two Parities where either Party, at the time either party accepts or accedes to GPA, does not consent to such application. This statement seems to offer a choice for the acceding member, such as China to accede to GPA if the bilateral negotiation with any GPA party such as the United States is proven to be failed. However, this is not in line with the interests of either China or the United States because of the large government procurement market they both have and no precedent in practice. Moreover, the "poison pill" clause in USMCA also show that the United States is not likely to accept that China accedes to GPA and achieve great government procurement market opportunities with other countries.

\section{China's Possible Countermeasures}

Chinese government already announced to accelerate the accession to GPA as a significant part of its market opening strategy. The great game between China and the Unites States will last for a long period and the possible countermeasures China might use in the following negotiation for accession to GPA are listed in the following paragraphs.

\subsection{Responding to GPA Parties' Key Concerns in Accession Negotiations}

\subsubsection{Submitting Revised Offer in the Same Level of Existing GPA Parties}

The government procurement market opening under the GPA follows the principle of reciprocity and balance. GPA Parties including the United States and the European Union reaches agreement on government procurement through the intense negotiation process. Therefore, GPA parties expect China's government procurement market to be as open as theirs.

The Chinese government procurement scale is 3.21143 trillion RMB in 2017 , accounting for the $12.2 \%$ of fiscal expenditure and $3.9 \%$ of GDP. These proportions seems to be much less than the indicators generally accepted to be the proper scale of government procurement in a country which are $30 \%$ and $15 \%$ respectively. The main concern about the differences is that most state-owned enterprises in China have still not been covered although 1China might respond to these challenges in the following aspects. Firstly, The state-owned enterprises in China is different from those in the United States and European Union since most of them are involved in market competition and enjoy the same rights and responsibilities as other business entities. The procurement of state-owned enterprises in China is not regulated by its Government Procurement Law. It is unrealistic for Chinese government to cover most state-owned enterprises immediately when the related domestic law is still in the process of reform. Secondly, China will not choose to cover most state-owned enterprises even under the 
principle of reciprocity. The purchasing scale of Chinese state-owned enterprises is much more than Chinese government due to the large part they account for in China's economy. The opening procuring opportunities will be more than other GPA parties if China covered all state-owned enterprises without differentiating commonweal and for-profit enterprises since most GPA parties including the United States only cover few non-profit state-owned enterprises and do not cover any for-profit state-owned enterprises with independent operation. This disobeys the GPA principle of reciprocity. Thirdly, precedents exist in the current GPA parties to accede to GPA with a smaller coverage and broaden it with full preparation in domestic law and development. For instance, Canada did not open the procurement market of the state-owned enterprises as soon as it acceded to GPA because of their market-oriented operation.

\subsubsection{Special Treatment as a Developing Country}

The Trump administration has been arguing that China enjoys the unfair special treatment which is not equal to its economic status and WTO should improve its definition about "developing countries". The insistent at acceding GPA as a developing country with special treatment such as the transition period seems not to be abandoned by Chinese government which can be shown in it latest revised offer. When estimating in purchasing power parity, China's GDP per capita is much less than the developed countries such as the United States. The entry into GPA as a developing country will also be helpful to attract more developing countries as the GPA is continuously working for.

\subsection{3 "Buy Local Goods" Provisions}

Article 10 of China's Government Procurement Law is paid great attention by the GPA parties including the United States in the negotiations of China's accession to GPA and is required to be deleted. The "Buy American" laws and regulations are still in force and the Trump Administration is accessing domestic laws and international agreements based on "Buy American" provisions. Chinese government might also keep this article in domestic law and commit the waiver of discriminatory regulations after acceding to GPA.

\subsection{Opening Government Procurement Market Through Bilateral Trade Agreements and Regional Trade Agreements}

China has signed FTAs with Switzerland, South Korea, Iceland and Australia with the article about government procurement. The negotiations on government procurement are agreed by the parties of FTAs to be commenced as soon as possible after the completion of negotiations on China's accession to GPA. The precedence of acceding to GPA in Chinese government's market opening strategy is confirmed by the above agreements. However, it is possible for Chinese government to move forward first through bilateral trade agreements and regional trade agreements especially when the United States is about to use more "poison pill" clauses to interfere in China's completion of FTAs with other countries.

\subsubsection{Bilateral Trade Agreements}

Bilateral trade agreements can lead to trade diversion.(Clausing, 2001) The country which enters into FTA on government procurement with China will achieve advantages in China's large government procurement market. This trade diversion effect will stimulate and accelerate the progress of negotiations between China and other countries on government procurement.

The United States also opens its government procurement market through FTA to GPA parties or non-GPA parties. Switzerland, South Korea and Australia are both parties of GPA and of FTAs with China with the commitment to commence negotiations on government procurement. The bilateral negotiation with them about opening more purchasing opportunities to each other will be helpful for accelerating China's accession to GPA. The latest offer might be accepted by Switzerland, South Korea and other smaller economy though the United States and European Union still need more negotiations.

\subsubsection{Regional Trade Agreements}

Regional trade agreements is another applicable tool to open government procurement market. The other parties signed Comprehensive Progressive Trans-Pacific Partnership (CPTTP) with the same government procurement chapter although the United States exits TPP. Malaysia and Vietnam which are not GPA parties open part of their government procurement market for the first time in CPTTP.

The negotiation under the framework of regional trade agreements can foster GPA parties to treat China's offer in a more pragmatic way with a view to concluding commitments on government procurement. The negotiation of Regional Comprehensive Economic Partnership (RCEP) led by China has seen great improvement and the Chapter of government procurement is to improve the transparency of laws, regulations and procedures and to 
promote the cooperation in government procurement. The Chinese government might also achieve greater progress in opening government procurement market through One Belt and One Road initiative.

\subsection{Improving Domestic Laws and Regulations to Balance the Principle of Public Policy and GPA}

The construction of domestic legal system aims at protecting national interests and providing support for negotiations acceding to GPA and opening government procurement market. Chinese government is working in the following two aspects in the reform of Chinese government procurement law.

Firstly, Chinese government is to strengthen the completion of domestic legal system to protect the national interests as well as approaching to the international rules. There are two government procurement laws in China including Government Procurement Law and Bidding Law which are drafted and governed by Ministry of Finance and National Development and Reform Commission of China respectively. This causes differences and arguments in government procurement in China. The unification of the two laws and the regulations based on them is the main challenge for the reform of Chinese legal system of government procurement while the reform of laws on state-owned enterprises are also of great importance.

Secondly, Chinese government is to fulfill the public policy function of government procurement through exceptions in GPA. The sustainable development is an exception in GPA to non-discriminatory principle, including environment protection, energy conservation, development of small and medium enterprises (SME) and undeveloped areas. Innovation is also what government procurement aims at. Chinese government canceled some supportive policies to innovations of local enterprises due to the pressure caused by negotiations acceding to GPA. However, 2017 USTR Report to Congress on China's WTO Compliance claimed that Chinese government never implement its commitment to cancel preferential policies to local enterprises for innovation. The Service of Research and Development is excluded from the U.S. offer to GPA and government procurement is still the most important tool for innovation in high-tech development. It is the tendency that Chinese government also uses government procurement to prompt the high-tech improvement.

\section{Conclusion}

China's attitude toward joining the GPA has shifted from passive to active, while the US government is slipping into trade protectionism. The latest agreement reached on their "phase one"trade deal by the US and China in December 2019 came with better expectations for the relationship between the two great powers in the world. Although it seems not to be the best choice for the US to abandon GPA or stall China's accession to GPA, the Chinese government should also make preparation for the potential negotiation after its latest revised offer submitted. China might continue to actively prepare for the GPA to improve the domestic government procurement system, use multilateral, regional, bilateral and other trade mechanisms to advance the United States and other developed countries to accept China's accession to the GPA, make good use of the reciprocity principle advocated by the United States while attaching importance to the purchasing domestic goods laws and policies, and promote the opening of the government procurement markets with the other countries participating in the negotiations.

\section{References}

Anderson, R. D., \& Arrowsmith, S. (2011). The WTO Regime on Government Procurement: Past, Present and Future. In Sue Arrowsmith \& R. D. Anderson (Eds.), The WTO Regime on Government Procurement: Challenge and Reform (pp. 3-58). Cambridge: Cambridge University Press. https://doi.org/10.1017/CBO9780511977015.005

Anderson, R. D., Müller, A. C., Osei-Lah, K., Leon, P. D. L., \& Pelletier, P. (2011). Government procurement provisions in regional trade agreements: a stepping stone to GPA accession? In Sue Arrowsmith \& R. D. Anderson (Eds.), The WTO Regime on Government Procurement: Challenge and Reform (pp. 561-656). Cambridge: Cambridge University Press. https://doi.org/10.1017/CBO9780511977015.024

Arrowsmith, S. (2003). Government Procurement in the WTO. United Kingdom: Kluwer Law International.

Cao, F. G., \& He J. C. (1998). Government Procurement Management International Norms and Practices [M]. Beijing: Enterprise Management Press.

Cao, F. G. (2008). The Significance, Challenges and Future of China's Initiation of WTO-GPA Negotiations [J]. China Government Procurement, 10, 72-75.

Clausing, K. A. (2001) Trade creation and trade diversion in the Canada - United States Free Trade Agreement [J]. Canadian Journal of Economics/revue Canadienne Déconomique, 34(3), 677-696. https://doi.org/10.1111/0008-4085.00094 
European Commission. (2003). Report on United States Barriers to Trade and Investment, Brussels: European Commission. Retrieved from http://aei.pitt.edu/42332/1/2003_barriers.pdf

Federal Register Notice with 2018-2019 Thresholds (82 FR 58248, Dec. 11, 2017). Retrieved from https://ustr.gov/sites/default/files/files/Issue_Areas/GovernmentProcurement/2017-26597.pdf

Feis, R. B. H. (1947). Suggested Charter for an International Trade Organization of the United States by United States Department of State. Journal of Political Economy, 55(1), 84-85. https://doi.org/10.1086/256475

Harutyunyan, S. (2016). Risk and Expectation in Exclusion from Public Procurement: Understanding Market Access and Harmonization Between the European Union and the United States. Public Contract Law Journal, 45, 449-476.

Hoda, A. (2019). Where Is US Trade Policy Headed Under the Trump Administration? In Kathuria R., \& Kukreja P. (Eds.), 20 Years of G20 (pp. 81-92). Singapore: Springer. https://doi.org/10.1007/978-981-13-8106-5_4

Jia, G. L. (2018). "Zhongxing Incident" sounded the alarm for China's accession to the WTO Government Procurement Agreement [J]. Learning and Exploration, 8, 113-121+194.

Liu, H. (2003). Introduction to the World Trade Organization Government Procurement Agreement [M]. Beijing: Chinese Social Sciences Publishers.

Liu, H. (2007). 10 Years of Government Procurement Reform: Retrospect, Thinking and Prospects [J]. Chinese Government Procurement, 1, 4-7.

National Security Strategy of the United States. (2015). Retrieved from http://nssarchive.us/wp-content/uploads/2015/02/2015.pdf

National Security Strategy of the United States. (2017). Retrieved from https://www.whitehouse.gov/wp-content/uploads/2017/12/NSS-Final-12-18-2017-0905-2.pdf

Office of the United States Trade Representative. (2016). Trade Policy Agenda. Retrieved from https://ustr.gov/sites/default/files/2016-Trade-Policy-Agenda.pdf

Office of the United States Trade Representative. (2018). 2018 Trade Policy Agenda and 2017 Annual Report of the President of the United States on the Trade Agreements Program. Retrieved from https://ustr.gov/about-us/policy-offices/press-office/reports-and-publications/2018/2018-trade-policy-agend a-and-2017

Stiglitz, J. E. (2017). Globalization and Its Discontens Revisited:Anti-Globalization in the Era of Trump [M]. New York: W.W. Norton.

Summary of the 2018 National Defense Strategy of the USA. Retrieved from http://nssarchive.us/wp-content/uploads/2018/01/2018-National-Defense-Strategy-Summary.pdf

U.S. Government Accountability Office. (2019). Report to Congressional Requesters. INTERNATIONAL TRADE: Foreign Sourcing in Government Procurement. Retrieved August 19, 2019 from https://www.gao.gov/assets/700/699393.pdf

Weiss, L., \& Thurbon, E. (2006). The business of buying American: Public procurement as trade strategy in the USA [J]. Review of International Political Economy, 13(5), 701-724. https://doi.org/10.1080/09692290600950597

Yong, W. (2019). Interpreting US-China Trade War Background, Negotiations and Consequences [J]. China International Strategy Review, 1-15. https://doi.org/10.1007/s42533-019-00019-6

Yu, A. (2003). A Preliminary Analysis Report on China's Accession to the WTO Government Procurement Agreement. In WTO Law and China Forum" Collection - Proceedings of the Annual Meeting of the World Trade Organization Law Research Society of the Chinese Law Society, II, 156-158.

Yu, A. (2005). The Impact of Joining the Government Procurement Agreement on China's Law System [J]. Law, 6, 29-35.

Yu, A. (2010). Legislative Issues on Policy-based Government Procurement [J]. Chinese Government Procurement, 2, 14-16.

Yukins, C. R. (2017). The Trump Administration's Policy Options in International Procurement. 2016 West Gov. Contracts Year in Rev. Sess. 2-I (Feb. 2017); GWU Law School Public Law Research Paper No. 2017-8; GWU Legal Studies Research Paper No. 2017-8. Retrieved from https://papers.ssrn.com/abstract=2925953 
Yukins, C. R. (in press). Two U.S. Initiatives on a Collision Course: Trump's Buy American Order and the New Electronic Marketplaces [J]. Public Procurement Law Review.

Yukins, C. R., \& Schooner, S. L. (2007). Incrementalism: Eroding the Impediments to a Global Public Procurement Market. Georgetown Journal of International Law, 3, 529-576.

\section{Copyrights}

Copyright for this article is retained by the author(s), with first publication rights granted to the journal.

This is an open-access article distributed under the terms and conditions of the Creative Commons Attribution license (http://creativecommons.org/licenses/by/4.0/). 